\title{
Emergence of Congenital Zika Syndrome: Viewpoint From the Front Lines
}

Federico Costa, PhD; Manoel Sarno, MD, PhD; Ricardo Khouri, PhD; Bruno de Paulo Freitas, MD; Isadora Siqueira, MD, PhD; Guilherme S. Ribeiro, MD, PhD; Hugo C. Ribeiro, MD; Gubio S. Campos, PhD; Luiz C. Alcântara, PhD; Mitermayer G. Reis, MD, PhD; Scott C. Weaver, PhD; Nikos Vasilakis, PhD; Albert I. Ko, MD; and Antonio Raimundo Almeida, MD

ika, a mosquito-borne flavivirus discovered in Uganda in 1947, remained obscure until its emergence in Micronesia in 2007. Six years later, it arrived in French Polynesia and other islands in the South Pacific (1). The virus was first detected in Brazil in early 2015 and has now spread throughout South and Central America and the Caribbean (2). Infection often remains unrecognized because it is either asymptomatic (75\% to $80 \%$ ) or has a nonspecific presentation of rash and fever. The first suggestion that Zika virus causes more than a self-limited illness was during the French Polynesian outbreak, when incidence of Guillain-Barre syndrome increased 20-fold (3). Likewise, a cluster of cases of this syndrome was identified in Brazil after the introduction of Zika virus (4).

From July to September 2015, several months after the introduction of Zika virus into northeastern Brazil, obstetricians noticed an increased number of fetuses with congenital malformations during ultrasound screening. By October, the number of newborns with microcephaly had increased significantly in this area, according to birth registry data from previous years. Microcephaly had now risen in other regions along with the spread of Zika virus. To date, more than 4000 cases have been reported (Figures 1 and 2).

That Zika virus is the cause of the large number of microcephaly cases identified during the epidemic remains presumptive (5). Brazilian researchers first noted the virus's potential association with microcephaly when they investigated a newborn with this condition, who died soon after birth and was found to have detectable virus in tissues. Subsequently, Zika virus RNA was detected in additional cases of fetuses and stillbirths with congenital malformations (6-8). To date, the strongest evidence of the correlation between Zika virus and microcephaly is a circumstantial link between the spatial and temporal patterns of these infections and the appearance of microcephaly. In addition, this condition was retrospectively identified in infants born during the 2013 outbreak in French Polynesia. Despite these observations, investigators have not determined a definitive association between Zika virus and microcephaly cases in the Brazilian outbreak, most of which have been live-born infants.

Our investigation is still in progress; however, we have gained insight into the scope and severity of microcephaly due to presumed congenital Zika syndrome (CZS), as well as challenges in confirming this association. Microcephaly is characterized by severe manifestations, such as marked cerebral atrophy and ventriculomegaly, extensive intracranial calcifications, simplified
Figure 1. Distribution of incident cases of microcephaly among Brazilian newborns, according to epidemiologic week and geographical region from 15 November 2015 to 16 January 2016.

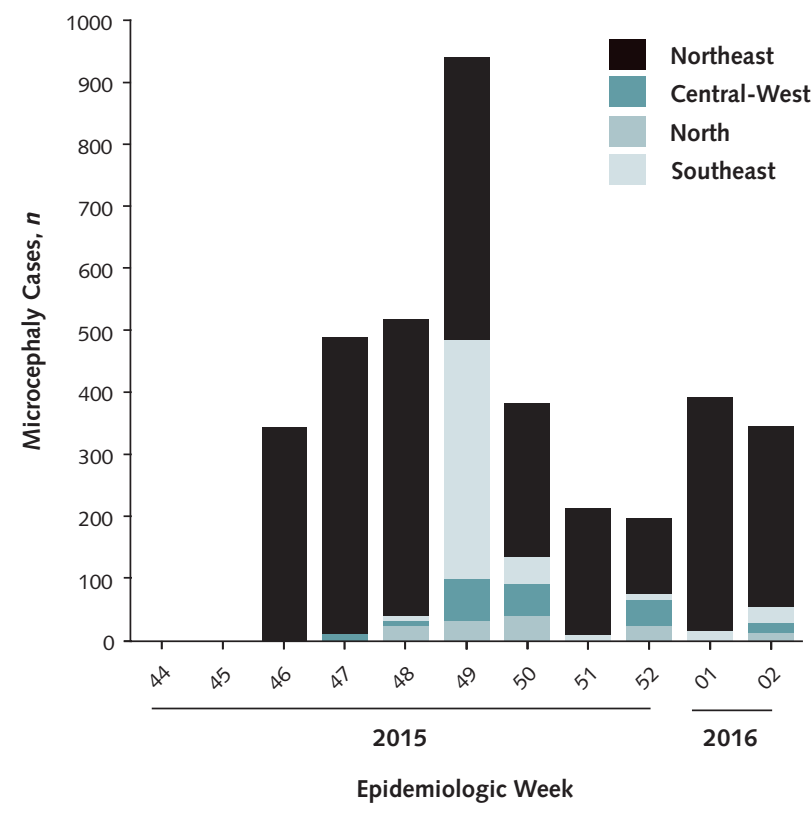

From the Brazilian Ministry of Health.

gyral patterns, dysgenesis of the corpus collosum, and cerebellar hypoplasia (Figure 3). Furthermore, CZS manifestations that extend beyond the central nervous system have been observed, including auditory impairment as well as ocular manifestations (9), such as focal pigment mottling and chorioretinal atrophy, which are distinct from other congenital conditions. Similar ocular lesions have been anecdotally identified in normocephalic newborns, suggesting that the overall burden may not be restricted to microcephaly cases.

Although the apparent increase in microcephaly supports the assertion that Zika virus causes a distinct congenital syndrome, diagnostic limitations suggest caution in assuming a causal relationship. We have detected Zika virus RNA in only a fraction of microcephaly cases. Increased case ascertainment of microcephaly due to other causes has probably occurred contemporaneously. The inability to detect Zika virus in newborns with microcephaly may reflect compartmentalization of virus in tissues not sampled at the time of birth. Alter-

This article was published at www.annals.org on 24 February 2016. 
Figure 2. Cumulative cases of microcephaly according to federal state from 15 November 2015 to 16 January 2016.

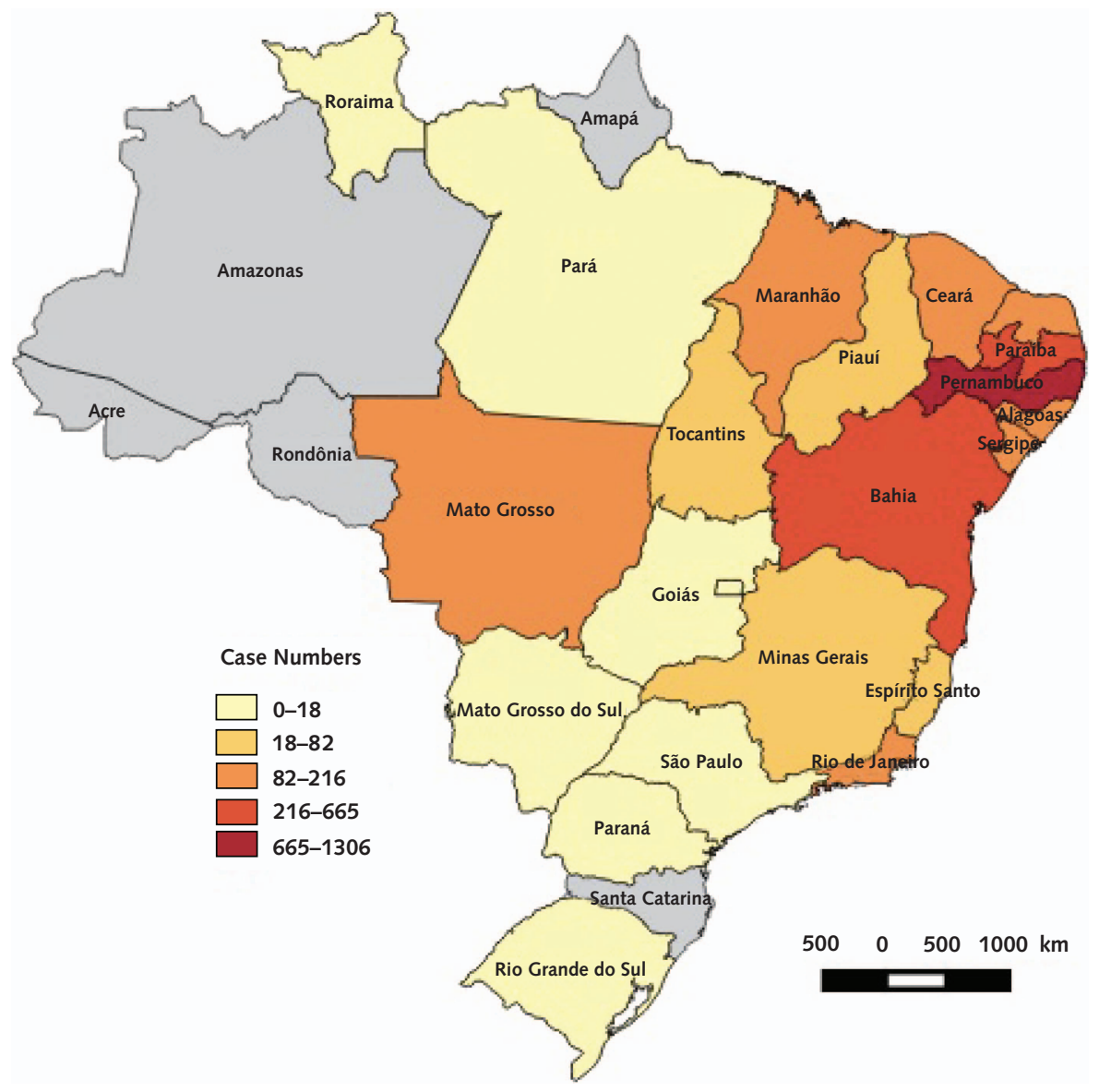

From the Brazilian Ministry of Health.

natively, intrauterine infections may be self-limited and Zika virus often cleared by birth.

Screening approaches are essential for pregnant women who reside in impoverished regions where Zika virus has been recently introduced and who do not have access to ultrasound and amniocentesis. Although detection is hampered by the extensive antigenic cross-reactivity with dengue and other circulating flaviviruses, a serologic test for prior intrauterine exposure to the virus in newborns is critically needed-not only for diagnosis in pregnant women and newborns but also to identify individuals who have been infected with Zika virus and are presumably immune to reinfection. A more accurate IgG assay is essential to stratify risk in women of childbearing age and to facilitate targeted prenatal screening. Molecular detection is unlikely to be available in many regions, and infections are asymptomatic.

Potential explanations for the recent explosion of Zika virus in the Pacific islands and the Americas and its continued spread are unclear but include recent genetic/phenotypic virus changes before or coincident with its disbursement beyond Asia. This could involve selection for enhanced infection of mosquito vectors, such as Aedes aegypti. Such vector-adaptive selection of more transmissible chikungunya virus strains has occurred since 2005. Other possibilities include selection for higher levels of human viremia in the urban cycle, which could increase the efficiency of transmission as well as enhance fetal infection.

A simpler explanation is that the outbreaks began when, by chance, the virus was introduced into naive populations at the right time and place for initiation of the human-mosquito cycle. If the virus is able to establish endemic or enzootic circulation (as has been suggested as occurring in Asia on the basis of seroprevalence data) stable herd immunity may prevent future epidemics, as well as CZS in Brazil. Further, genetic, pathogenesis, and vector infection studies with diverse virus strains combined with improved surveillance and better, more affordable diagnostics that can be deployed even in remote, resource-limited settings, are needed to evaluate these hypotheses.

Unfortunately, the immediate prospects for controlling the magnitude and spread of the current Zika virus epidemic are not promising. Until a vaccine is available, mosquito control and education of at-risk populations to reduce contact with the vector are the only short- 
Figure 3. Computed tomography, reconstructed in the coronal oblique plane, of a newborn with microcephaly.

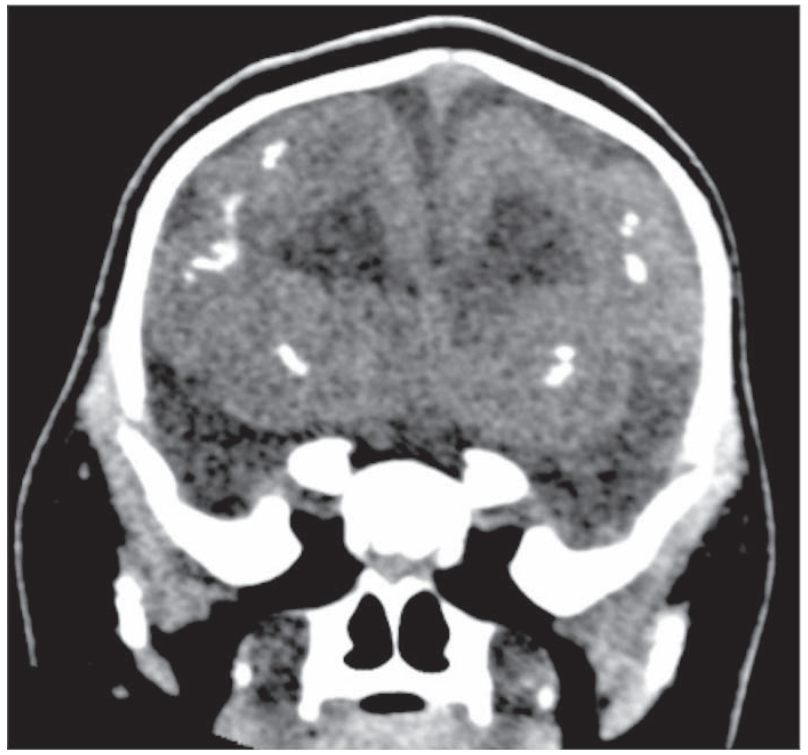

Craniofacial dysmorphism, subcortical and basal ganglia calcifications, simplified gyral pattern, ventriculomegaly, and dysgenesis of the corpus callosum are seen.

term approaches available. These methods have had limited success for dengue and chikungunya viruses.

Although recent advances in flavivirus vaccines may guide relatively rapid development of a Zika vaccine, availability is still probably years away. Treatment with a monoclonal antibody could also be developed quickly on the basis of promising past results with flaviviruses. However, systematic investigations of pregnant women and newborns will still be needed to determine the risk for transplacental infection and development of severe congenital sequelae that can, in turn, guide effective diagnostic and prevention efforts.

From Centro de Pesquisas Gonçalo Moniz, Fundação Oswaldo Cruz, Ministério da Sáude, Salvador BA, Brazil; Instituto da Saúde Coletiva and Faculdade de Medicina da Bahia, Universidade Federal da Bahia, Salvador BA, Brazil; Hospital Geral Roberto Santos, Secretaria Estadual da Saúde da Bahia, Salvador BA, Brazil; Institute for Human Infections and Immunity, and Department of Microbiology and Immunology, Department of Pathology, and The University of Texas Medical Branch, Galveston, Texas; and Department of Epidemiology of Microbial Diseases, Yale School of Public Health, New Haven, Connecticut.

Disclosures: Disclosures can be viewed at www.acponline .org/authors/icmje/ConflictOflnterestForms.do?msNum=M16 -0332 .

Requests for Single Reprints: Dr. F. Costa: Instituto de Saúde Coletiva, Rua Basílio da Gama S/N, Canela, Salvador, Bahia 40110-040, Brazil; e-mail, fcosta2001@gmail.com.

Current author addresses and author contributions are available at www.annals.org.

Ann Intern Med. doi:10.7326/M16-0332

\section{References}

1. Musso D, Cao-Lormeau VM, Gubler DJ. Zika virus: following the path of dengue and chikungunya? [Letter]. Lancet. 2015;386:243-4. [PMID: 26194519] doi:10.1016/S0140-6736(15)61273-9

2. Fauci AS, Morens DM. Zika virus in the Americas-yet another arbovirus threat. N Engl J Med. 2016;374:601-4. [PMID: 26761185] doi:10.1056/NEJMp1600297

3. Oehler E, Watrin L, Larre P, Leparc-Goffart I, Lastere S, Valour F, et al. Zika virus infection complicated by Guillain-Barre syndromecase report, French Polynesia, December 2013. Euro Surveill. 2014; 19. [PMID: 24626205]

4. Cardoso CW, Paploski IA, Kikuti M, Rodrigues MS, Silva MM, Campos GS, et al. Outbreak of Exanthematous Illness Associated with Zika, Chikungunya, and Dengue Viruses, Salvador, Brazil [Letter]. Emerg Infect Dis. 2015;21:2274-6. [PMID: 26584464] doi:10 .3201/eid2112.151167

5. Victora C, Schuler-Faccini L, Matijasevich A, Ribeiro E, Pessoa A, Barros F. Microcephaly in Brazil: how to interpret reported numbers? Lancet.2016;387:621-4.doi:10.1016/S0140-6736(16)00273-7.[PMID: 2686496]

6. Oliveira Melo AS, Malinger G, Ximenes R, Szejnfeld PO, Alves Sampaio S, Bispo de Filippis AM. Zika virus intrauterine infection causes fetal brain abnormality and microcephaly: tip of the iceberg? Ultrasound Obstet Gynecol. 2016 Jan;47(1):6-7. doi: 10.1002/uog .15831. [PMID: 26731034]

7. Mlakar J, Korva M, Tul N, Popovic M, Poljšak-Prijatelj M, Mraz J, et al. Zika Virus Associated with Microcephaly. N Engl J Med. 2016. [PMID: 26862926]

8. Martines R, Bhatnagar J, Keating M. Notes from the field: evidence of Zika virus infection in brain and placental tissues from two congenitally infected newborns and two fetal losses - Brazil, 2015. MMWR Morb Mortal Wkly Rep. 2016;65:159-60. [PMID: 26890059] doi: 10.15585/mmwr.mm6506e1.

9. de Paula Freitas B, de Oliveira Dias J, Prazeres J, et al. Ocular Findings in Infants With Microcephaly Associated With Presumed Zika Virus Congenital Infection in Salvador, Brazil. JAMA Ophthalmol. [PMID: 26865554] doi:10.1001/jamaophthalmol.2016.0267. 
Current Author Addresses: Dr. Costa: Instituto de Saúde Coletiva, Rua Basílio da Gama S/N, Canela, Salvador, Bahia 40110-040, Brazil.

Dr. Sarno: Hospital Geral Roberto Santos, Secretaria da Saúde do Estado da Bahia and Maternidade Climerio de Oliveira, Universidade Federal da Bahia, Rua do Limoeiro, 137, Nazaré, Salvador, Bahia 41055-150, Brazil.

Dr. Khouri: Centro de Pesquisas Gonçalo Moniz, Fundação Oswaldo Cruz/MS, Rua Waldemar Falcão, 121, Candeal, Salvador, Bahia 40296-710, Brazil.

Dr. de Paulo Frietas: Hospital Geral Roberto Santos, Secretaria da Saúde do Estado da Bahia, Av Paulo VI, 2240, Apt. 1004, Pituba, Salvador, Bahia 41810-001, Brazil.

Dr. Siqueira: Centro de Pesquisas Gonçalo Moniz, Funda, R. Waldemar Falcao, 121, Salvador, Bahia 40296-710, Brazil.

Dr. G. Ribeiro: Instituto da Saúde Coletiva, Universidade Federal da Bahia and Centro de Pesquisas Gonçalo Moniz, Fundação Oswaldo Cruz/MS, Rua Waldemar Falcão, 121, Candeal, Salvador, Bahia 40296-710, Brazil.

Dr. H. Ribeiro: Hospital Geral Roberto Santos, Secretaria da Saúde do Estado da Bahia, Salvador, Bahia, Brazil.

Dr. Campos: Instituto de Ciências da Saúde, Universidade Federal da Bahia, Salvador, Bahia, Brazil.

Dr. Alcântara: Centro de Pesquisas Gonçalo Moniz, Fundação Oswaldo Cruz/MS, Rua Waldemar Falcão, 121, Candeal, Salvador, Bahia 40296-710, Brazil.

Dr. Reis: Centro de Pesquisas Gonçalo Moniz, Funda, Rua Waldemar Falcão, 121, Salvador, Bahia 40296-710, Brazil.

Drs. Weaver and Vasilakis: Institute for Human Infections and Immunity, University of Texas, 301 University Boulevard, Galveston, TX 77555.
Dr. Ko: Department of Epidemiology of Microbial Diseases, Yale School of Public Health, 60 College Street, P.O. Box 208034, New Haven, CT 06520-8034.

Dr. Almeida: Hospital Geral Roberto Santos, Secretaria da Saúde do Estado da Bahia and Faculdade da Medicina, Universidade Federal da Bahia, Av Santa Luzia, 149/302, Ed Bosque Italia, Salvador, Bahia , 40295050, Brazil.

Author Contributions: Conception and design: F. Costa, M. Sarno, M.G. Reis, N. Vasilakis, A.I. Ko, A.R. Almeida.

Analysis and interpretation of data: F. Costa, M. Sarno, B.de Paulo Freitas, G.S. Ribeiro, H. Ribeiro, S.C. Weaver, Nikos Vasilakis, A.I. Ko.

Drafting of the article: F. Costa, M. Sarno, R. Khouri, B.de Paulo Freitas, G.S. Ribeiro, Nikos Vasilakis, A.I. Ko.

Critical revision of the article for important intellectual content: F. Costa, M. Sarno, B.de Paulo Freitas, I. Siqueira, G.S. Ribeiro, Luiz C. Alcântara, S.C. Weaver, Nikos Vasilakis, A.I. Ko.

Final approval of the article: F. Costa, M. Sarno, B.de Paulo Freitas, I. Siqueira, G.S. Ribeiro, M.G. Reis, S.C. Weaver, Nikos Vasilakis, A.I. Ko, A.R. Almeida.

Provision of study materials or patients: M. Sarno, B.de Paulo Freitas, I. Siqueira, H.C. Ribeiro, M.G. Reis, A.R. Almeida.

Obtaining of funding: M.G. Reis, A.I. Ko.

Administrative, technical, or logistic support: B.d.P. Freitas, H.C. Ribeiro, M.G. Reis, S.C. Weaver, A.R. Almeida.

Collection and assembly of data: F. Costa, M. Sarno, B. de Paulo Freitas, H.C. Ribeiro, Luiz C. Alcântara, A.I. Ko, A.R. Almeida. 